\title{
Investigate workers' health in the western industrial region, Mosul, Iraq
}

Salim Rabeea Znad¹, Mazin Nazar Fadhel ${ }^{1}$, Ayça Erdem Ünşar ${ }^{2}$

DOI. 10.21931/RB/2021.06.03.16

Abstract: The current study aims to determine the level of heavy metal contamination in the Western Industrial Region of Mosul City, northern Iraq. Heavy metals such as( $\mathrm{Pb}$ ، $\mathrm{Co}$ ، $\mathrm{Hg}$ ) are measured In the blood serum of 40 workers in the main industrial areas of Mosul City. It was compared with the control group of (40) people from Mosul university, Where is Far away from the industrial areas and all activities.

The results indicated a highly significant increase of $\mathrm{P}<0.001$ in the serum of the workers in the industrial areas compared with the control group. The study investigates the impact of heavy metals on the workers' health in the industrial areas who are in direct contact with them

Key words: Investigation, Heavy metals Pollution, Blood Serum, industrial Region.

\section{Introduction}

Industry areas are often associated with positive economic benefits such as job creation and increased standard of living; however, Industrial activities may also negatively impact the environment and human health. Industrial activities are dangerous to human health, as heavy metals, mainly $\mathrm{Hg}, \mathrm{Pb}$, and Cobalt (Co), are often released into the environment ${ }^{1}$.

Metals such as lead $(\mathrm{Pb})$, Cobalt $(\mathrm{Co})$, mercury $(\mathrm{Hg})$ are unknown Function in the environment ${ }^{2}$.

These metals are quickly released into the environment via anthropogenic activities, e.g., metal plating facilities, mining, and agricultural activities ${ }^{3}$.

Some of these metals are known to act as human mutagens and carcinogens and are associated with various human ailments such as cardiovascular, nervous system, blood and bone diseases, kidney failure, gingivitis, and tremors, among others ${ }^{4}$.

Mercury $(\mathrm{Hg})$ is present in the Earth's crust. Although present in the environment and atmosphere in small quantities, it is release through anthropogenic emissions. Mercury toxicity is not limited to humans; it is also toxicity to animals and plants ${ }^{5}$.

Natural sources of mercury in the environment include mercury vapor from volcanoes and forest fires. More recent anthropogenic sources include burning coal and fossil fuels, mining mercury, precious metal refinement, electrical and automotive part manufacture, chemical processing, and release through waste incineration, landfills, and industrial contamination of water systems ${ }^{6}$.

Cobalt (Co) is a typical toxic trace metal that is widely found in Industrial Waste. Environmental exposure to this toxic trace metal occurs primarily through smoking and industrial plant emissions, and contaminated food and water ${ }^{7}$. (Co) has a half-life period of 15-30 years and accumulates in the liver as the primary target tissue ${ }^{1}$. This toxic trace metal can cause liver or renal cell apoptosis in a low dose of exposure ${ }^{8}$.

Lead $(\mathrm{Pb})$ is the third most abundant metal on the planet and is highly available in soil and water. Due to its impacts on the environment and human health, the scientific community is interested in investigating both issues, especially when considering that humans are mainly exposed to) $\mathrm{Pb}$ ) through drinking water, household goods, cosmetics, and drugs ${ }^{9}$. Then, the $(\mathrm{Pb})$ ability to cross the blood-brain barrier features its tropism for the central nervous system ${ }^{10}$. Modulating cell biochemistry and tissue integrity and may drive behavioral dysfunctions ${ }^{11}$.

Researchers such as (12) indicated in their study about measuring the concentrations of heavy metals ( $\mathrm{Pb}, \mathrm{Ni}, \mathrm{Co}, \mathrm{Fe}$ $\mathrm{Cu}, \mathrm{Zn}$ ) in serum blood comparison of The industrial workers with the control group (employees of the University of Mosul), that there are Hight significant increase og Heavy metals in the serum of the workers who are in the industrial areas compared with the control group.

\section{Materials and methods}

\section{Study Area}

The study area is the city of Mosul, which is located in the western part of Iraq, between the longitude of $41^{\circ}-44^{\circ}$ and the latitude of $35^{\circ}-37^{\circ}$. In particular, the industrial region of the city is the manufacture of the Wadi Okab on the right side (the western part) (Figure 1).

\section{Study Design}

The blood samples were taken from (40) industrial agents randomly and from two main areas, namely the manufacture of the Wadi Okab (right side) industry. In addition to taking blood samples from (40) people as a control group working at Mosul University and without a history of industrial activity. The control group is not different from workers in terms of gender and age groups.

\section{Demographic information}

Participant demographic information was collected using a researcher-made questionnaire. Information was further verified by cross-checking with medical records (age, gender, number of years spent at work, smoking cases) $)^{13}$.

\section{Ethics approval}

All participants in the study approved the study gave their permission to access their medical records, blood sampling, and anonymous use of their samples.

\footnotetext{
${ }^{1}$ College of Environmental Sciences and Technology, Depart. Of Environmental Sciences, University of Mosul.

${ }^{2}$ Faculty of Engineering. Department of Environmental Engineering. Akdeniz University.
} 


\begin{tabular}{|l|l|l|l|l|}
\hline Elements & Grouping & $\mathbf{N}$ & $\begin{array}{l}\text { Mean } \pm \text { SD } \\
(\mathbf{p p m})\end{array}$ & p-Value \\
\hline $\mathbf{P b}$ & Workers & 40 & $1.4050 \pm 0.66872$ & $\mathrm{p}<0.001$ \\
& Control & 40 & $0.7095 \pm 0.71500$ & \\
\hline $\mathbf{C o}$ & Workers & 40 & $0.9890 \pm 0.49871$ & $\mathrm{p}<0.001$ \\
& Control & 40 & $0.5545 \pm 0.50351$ & \\
\hline $\mathbf{H g}$ & Workers & 40 & $0.5590 \pm 0.69120$ & $\mathrm{p}<0.001$ \\
& Control & 40 & $0.3835 \pm 0.20709$ & \\
\hline
\end{tabular}

Table 1. Determination of heavy metals in Area of workers \& controls groups.

$P<0.05$ Significant $P>0.05$ No significant

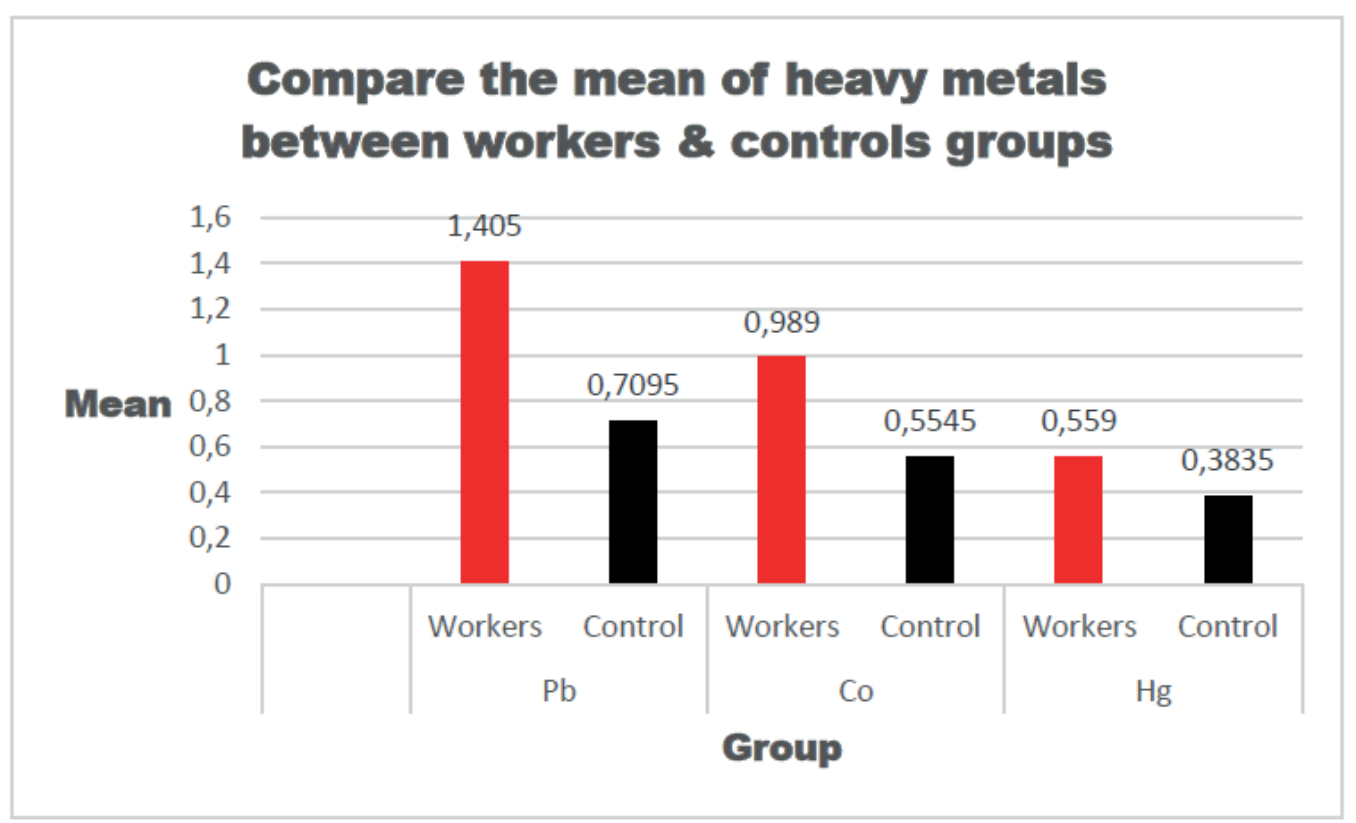

Figure 2. Compare the mean of heavy metals between workers \& controls groups.

11. Gauthier E, Fortier I, Courchesne F, Pepin P, Mortimer J,Gauvreau $D$. Aluminum forms in drinking water and risk of Alzheimers disease. Environ Res2000; 84(3):234-246.

12. Znad, Salim Rabee. and Al-Sinjary, MazinNazar . The vital accumulation of some Heavy metals in the blood serum of industrial zone workers in Mosul city. Plant Archive journal volume 2020; 20. Supplement 1, pp 3194- 3200 .

13. Kozlowski H, Brown DR, Valensin G. Metallochemistry of neurodegeneration: biological, chemical and genetic aspects.Royal Society of Chemistry,2007; London

14. Rashed MN. Total and extractable heavy metals in indoor, outdoor and street dust from Aswan City, Egypt. Clean - Soil, Air, Water [Internet]. 2008 Nov [cited 2015 May 25];36(10-11):850-7.

15. Satarug, S., Moore, M.R.. Adverse health effects of chronic exposure to low-level cadmium in foodstuffs and cigarette smoke. Environ Health Perspect 2004; 112, 1099-1103.

16. Sun G, Li Z, Bi X, Chen Y, Lu S, Yuan X. Distribution, sources and health risk assessment of mercury in kindergarten dust. Atmospheric Environ [Internet]. 2013 Jul [cited 2015 May 25];73:16976.

17. Verougstraete, V., Lison, D., Hotz, P... Cadmium, lung and prostate cancer: a systematic review of recent epidemiological data. J Toxicol Environ Health B Crit Rev 2003; 6, 227-255.

Received: 11 March 2021

Accepted: 10 July 2021 